\title{
Determination of Economic Threshold Level (ETL) of Jassid, Amrasca bigutulla bigutulla (Cicadellidae:Homoptera)
}

\author{
Shoaib Nawaz ${ }^{1}$, Muhammad Razaq ${ }^{1}$, Zahid Mahmood Sarwar ${ }^{1 *}$, Muhammad Sajjad ${ }^{1 *}$, Syeda Aneeza \\ Ubaid $^{1}$, Muhammad Asif Zulfiqar ${ }^{2}$ and Usman Haider ${ }^{1}$
}

${ }^{1}$ Department of Entomology, FAST, Bahauddin Zakariya University, Multan, Punjab, Pakistan; ${ }^{2} P A R C$, Research and Training Station Bahauddin Zakariya University, Multan, Punjab, Pakistan.

Abstract | Okra, Abelmoschus esculentus (Moench) is most important vegetable crop of Pakistan and considered a heat loving plant cultivated in kharif and Rabi season. Okra fruit due to its nutrients like protein vitamin calcium potassium, value play an important role in Ghanaians diet. Sucking pest jassid become major problem on okra in tropical and subtropical regions and cause heavy losses. Neonicotinoid insecticide, like nitenpyram was used on calendar basis and ETL basis. Data was recorded on weekly basis. In first week jassid population in control and ETL treatments was equal with non-significant difference between them while in calendar treatment population was significantly low. ETL and calendar base treatments give maximum yield because numbers of pest in both treated plots remain control.

Received | August 13, 2018; Accepted | November 16, 2018; Published | December 13, 2018

*Correspondence | Zahid Mahmood Sarwar, Department of Entomology, FAST, Bahauddin Zakariya University, Multan, Punjab, Pakistan; Email: zmsarwar2bzu.edu.pk.; Muhammad Sajjad, Department of Entomology, FAST, Bahauddin Zakariya University, Multan, Punjab, Pakistan; Email: sajjad8676@gmail.com

Citation | Nawaz, A., M. Razaq, Z.M. Sarwar, M. Sajjad, S.A. Ubaid, M.A. Zulfiqar and U. Haider. 2019. Determination of economic threshold level (ETL) of jassid, Amrasca bigutulla bigutulla (Cicadellidae:Homoptera). Pakistan Journal of Agricultural Research, 32(1): 28-32.

DOI | http://dx.doi.org/10.17582/journal.pjar/2019/32.1.28.32

Keywords | Nitenpyram, Calendar, ETL, Jassid, Okra Plants

\section{Introduction}

$V$ egetables are essential components of dietary prototype, because vegetables are highly nutritious have low calories and play a key role in health perfection and disease prevention. Risk of coronary heart disease (CHD) anticipated by maximum consumption of vegetables. About 5.2 million deaths were accredited worldwide in 2013 due to diets lacking vegetables (Manero et al., 2017). Vegetables included more than 5000 Phytochemicals. Some phytochemicals are act as a strong antioxidants and reduce risk of chronic disease and free radicals by modifying metabolic activity and detoxification of carcinogens (Liu, 2003).
Okra is one of the most common vegetable crops grown in Pakistan, which need average temperature and unable to bear low and high temperature for long time and it required high amount of water (Akbar and Khan, 2015). This crop is very susceptible from initial stages to insect pests, almost 72 insects species have been reported on okra (Srinivasa and Rajendran, 2003). Among these insects Jassid is a very notorious pest of many agricultural crops in Pakistan. Both immature and adult stages causes' huge loss by feeding on under sides of leaves and sucks the sap from leaves. The nymph of jassid prefer okra crop for the survival and feeding (Sharma and Singh, 2002) causes damage from seedlings to the fruit setting stage, and resulting 
loss up to 50-63.41 \% in yield (Sharma and Sharma, 2001). Moreover, this insect after feeding caused a decline of $49.8 \%$ and $45.1 \%$ in plant height and leaves size (Rawat and Sadu, 1973). Infected leaves curl upward from edges and dead brown spots with a yellow halo at the edge are developed, in severe condition of attacked leaves may dehydrated and fall down (Schreiner, 2000). Ultimately plant growth affecting and reduction in fruit numbers, taste, size and yield occur. During feeding A. bigutulla also inject the toxic material that seriously damaged the leaves, which look like as burning and finally fall down. (Jayasima et al., 2012; Jayarao, etal., 2015).

Several methods are used to minimize or control jassid including biological control, mechanical control, cultural control etc., but the most effective and rapid control is obtained by chemical control (Chinniah and Ali, 2000). Insecticides applications are one of the quickest options to save crop from harmful insect pests especially jassid. Insecticides remain essential components for pest management by vegetable growers where they are grown as cash crops. Chemical control is considered as vital components of in IPM and extensively reduce yield losses cause by jassid (Akbar et al., 2012). Different insecticides are recommended to control jassid but at fruiting stage conventional insecticides are not recommended because fruits are harvested frequently. Neonicotinoids are most effective for jassid management (Hemadri et al., 2018).

Due to injudicious and indiscriminative use of pesticides which not only enter in the vegetable but it also contaminates the water and air and enters in the food chain including human consumption of contaminated okra fruits (Subhani, 2001). In IPM strategy different technique are used collectively to minimize the application of insecticide for jassid management to get healthy and insecticide free vegetables.

Considering the importance of vegetable in diet, current research was purposed to use insecticide on ETL and calendar basis against A. bigutulla bigutulla for sustaining the fruit yield of okra under field conditions.

\section{Materials and Methods}

Field experiment was conducted at experimental farm area of Agriculture department of Bahauddin Zakariya University Multan (Latitude 30.257404 $\mathrm{N}$ and longitude $71.514334^{\circ} \mathrm{E}$ at altitude $710 \mathrm{~m}$ ), Punjab, Pakistan during 2017. Seed was sown on $7^{\text {th }}$ March 2017. Seeds variety "Sabz Pari" purchased from local market and sown in well prepared ridges and using RCBR design with 3 treatments such as calendar, ETL and control and 3 replications. The distance between blocks and treatments were $0.5 \mathrm{~m}$ and $1.68 \mathrm{~m}$ respectively. Treatment length and width were $4.5 \mathrm{~m}$ and $1.75 \mathrm{~m}$ respectively. Each treatment was repeated 3 times in rows with the distance of 45 $\mathrm{cm}$ between the rows with $9 \mathrm{~cm}$ plant-plant distance. Each treatment was set with 3 rows and the distance was $45 \mathrm{~cm}$ and plant to plant $9 \mathrm{~cm}$. Standard culture practices like irrigation and weeding were performed weekly till end crop season. A neonicotinoid insecticide, nitenpyram (Capstar tablets, Bayer Crop Sciences), was used by calendar and ETL application. Dose of $5 \mathrm{ml}$ in 6 liters of water was prepared and applied 6 times during the research. In calendarbased treatments, nitenpyram applied weekly and in ETL based treatment applied when 1 jassid (nymph or adult) recorded per plant. Control plots were not treated with pesticides.

\section{Data collection for ETL}

The periodical calculations of injured fruits and leaves were preserved from each plant, where the fruit and leaves have been inspected for Jassid. However, when the level of spray was attained, the plants were sprayed after one day with the suitable insecticides, depending upon to the pest situation.

Ten plants were selected from each treatment and observed three leaves from top, three leaves from middle and three leaves from lower portion of the plant. Nitenpyram was sprayed with a hand operated knapsack sprayer at a pressure of a hollow cone nozzle. Nitenpyram were applied six times in plots that designated as Calendar treatments. Three treatments of nitenpyram were applied in plots whenever $A$. bigutulla bigutulla was reached at ETL. No insecticides were applied in control plots. Jassid population was recorded on weekly bases from initial stage to harvesting stage. Fruit yield was harvested 2 times in a season, first picking on the $11^{\text {th }}$ May and $2^{\text {nd }}$ picking was done on $18^{\text {th }}$ May 2017 from all sprayed and control plots. The research data was analyzed by the statistical analysis. The economic threshold level for Jassid was calculated by manually counting. 


\section{Results and Discussion}

Impact of three treatments on population density of jassid nymphs were recorded on different dates. At first sampling date, there was no significant difference of jassid abundance among three treatments. At the second sampling date, densities of jassid nymph were comparatively lower in control plots when compared with ETL base and calendar treatments. Whereas in the subsequent sampling dates (from April $26^{\text {th }}$ to May $10^{\text {th }}$ ) the population of jassid was significantly higher in the control plots as compared to other treated plots. Frequently there was non-significant difference between calendars or at ETL basis plots treated with nitenpyram. On May $17^{\text {th }}$ sampling date, the density of jassid nymph in control and ETL treatments equal and had no significant difference between them while in calendar treatment population was significantly low (Figure 1). Results indicate that yield of ETL and calendar treatments have significant difference when compared with control but non-significant when compared ETL treatment with calendar treatment (Figure 2).
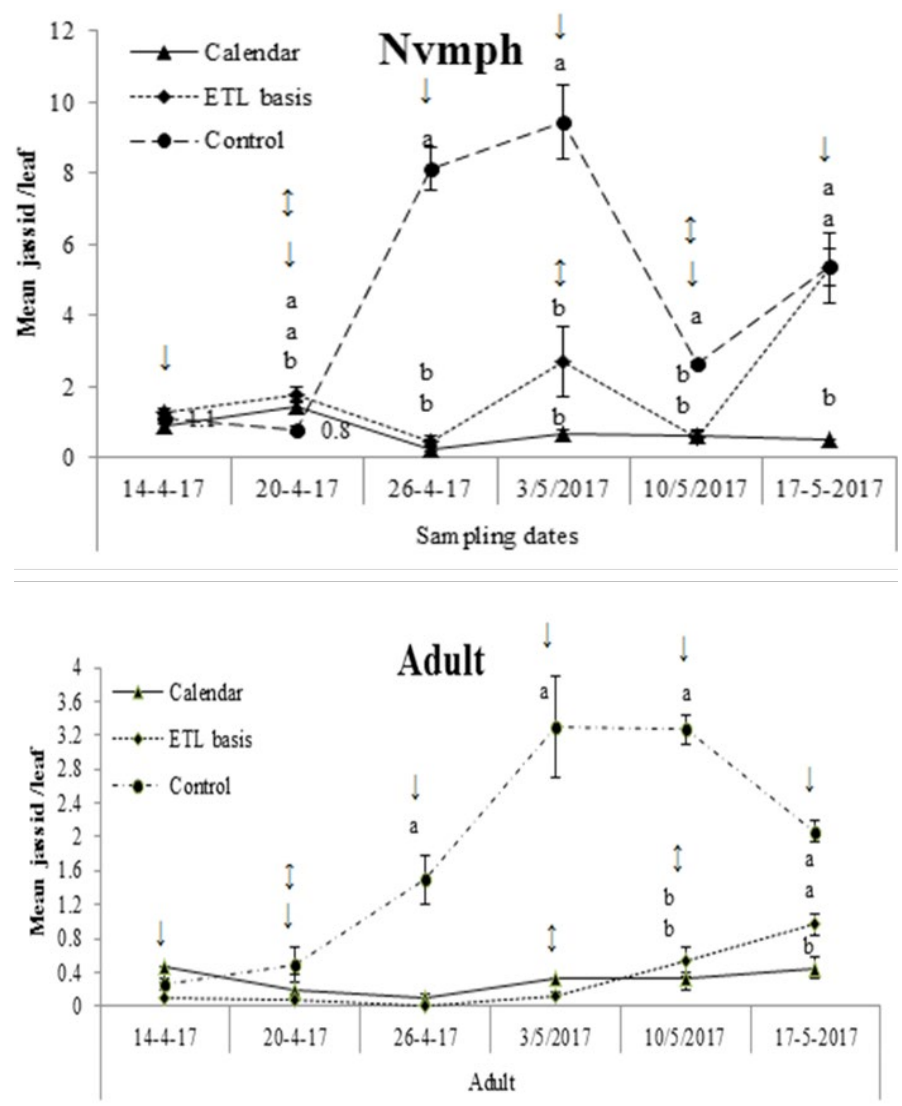

Figure 1: Comparison of Jassid densities between nitenpyram applied at ETL and Calendar basis comparison with control. Mean values on sampling dates labeled with sing headed arrow indicates the date of spraying of nitenpyram at calendar basis whereas double headed arrows indicated its application whenever jassid reached to ETL.
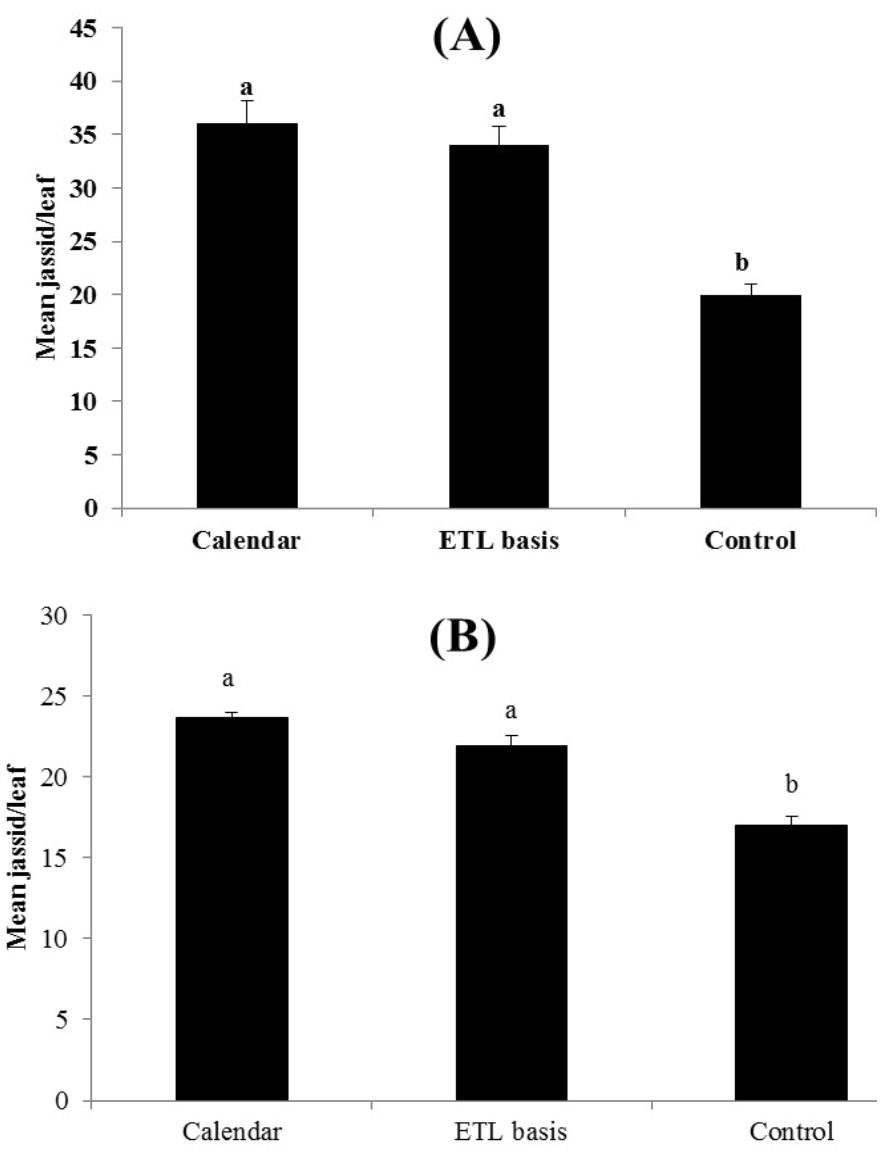

Figure 2: Mean okra yield obtained from nitenpyram sprayed (at calendar and ETL basis) and control plots. Bars labeled with common letters are significantly different at $P<0.05$.

Decision for action threshold is totally dependent of several factors such as market price of the commodities, pesticides cost, labor cost of pesticide application and their efficacy. Fruit production of okra is increased with the use of insecticides against pest management. In current manuscript neonicotinoid insecticide was used on calendar and ETL based for jassid control on okra crop. Our results compile with the findings of (Sharma et al., 2015) indicates that the new generation insecticides against sucking pest improved the marketable yield of okra fruits without affecting the environment. According to results calendar treatment obtain high yield as compare to other two treatments. It is indicated that schedule application of thiomethoxam $25 \mathrm{WG}$ is very fruitful for the management of sucking pests on okra plant. Our finding relate with the findings of (Zala, 2013), reported that schedule application was considered most effective than ETL based application due to low pest damage was recorded in calendar application. Our results defended by the results of (Misra and Senapati, 2003), informed that calendar application of insecticides for jassid control increased the yield of the okra fruits. According to (Mandal et al., 2006) 
concluded that calendar-based spray of endosulfan gave better protection to okra plants against jassids and other fruit borer and marketable yield were also improved. The yield of two treatments calendar and ETL high as compare to control treatment. There were no significant differences difference between calendar base and ETL treatments, reason is that at calendar base we applied nitenpyram spray at weekly bases and not developed the jassid population. ETL strategy improved the productivity of crops due to timely tracing of pest and taking action of nitenpyram for the prevention of jassid.

The saleable fruit production of okra was high at $2 \%$ and $4 \%$ ETL based application but 4\% ETL is very effective because it replaced the unnecessary application of insecticides on the crops (Kaur et al., 2015). For the population buildup of jassid maximum temperature are very important for the population enhancement and humidity also effective for the population. The similar work also reported that (Bhute et al., 2012) maximum temperature and humidity also very effective for jassid population. Our present finding shows that calendar basis and ETL treatments attain maximum yield and very low pest of jassid as compare to Control. While ETL help to farmer for buildup pre planed management strategies against the jassid pest.

\section{Conclusions and Recommendations}

Calendar and ETL treatments gives the maximum yield as compare to control treatment the reason is that in the calendar base treatment and ETL treatment jassid population not developed to cause yield losses. ETL is very useful for vegetable growers and crop managers for quick decision making to timely tackle this pest through chemical spray application.

\section{Author's Contribution}

Zahid Mahmood Sarwar: Conceived the idea, wrote Result and discussion and Conclusion, is the corresponding author.

Shoaib Nawaz: Wrote Abstract and Methodology. Muhammad Razaq: Proof checking Technical Input at every step.

Muhammad Sajjad: Analysis the Data, is also corresponding author.

Syeda Aneeza Ubaid: Data collection from field. Muhammad Asif Zulfiqar: Overall Management of the article and Incorporated reviewers comments.

Usman Haider: Wrote Introduction and set the References accordingly.

\section{References}

Akbar, M.F., M.A. Haq and N. Yasmin. 2012. Effectiveness of bio-insecticides as compared to conventionalinsecticides againstjassid (Amrasca devastans Dist.) on okra (Abelmoschus esculentus L.) crop. Pak. Entomol. 34: 161-165.

Akbar, R. and I.A. Khan. 2015. Population dynamics of insect pests on six okra varieties in Peshawar. J. Entomol. Zool. Stud. 3: 91-94.

Bhute, N., B. Bhosle, B. Bhede and D. More. 2012. Seasonal incidence of major sucking insect pests of Bt cotton and their natural enemies in Marathwada region. J. Cotton Res. Dev. 26: 238-242.

Chinniah, C. and K. Ali. 2000. Relative efficacy of insecticides/acaricides against sucking pests of okra. Pest Manage. Econ. Zool. 8: 111-116.

Hemadri, T., L. Vijaykumar, G. Somu and Sharanabasava. 2018. Management of leafhopper, Amrasca biguttula biguttula (Hemiptera:Cicadellidae) inokra (Abelmoschus esculentus ) through new insecticide molecules. Int. J. Chem. Stud. 6: 687-690.

Jayasimha, R., R. Rachana,M.Manjunatha and V.B. Rajkuma. 2012. Biology and sesonal incidence of leafhopper, Amrasca biguttulea biguttulea (Ishida) (Homiptera: Cicadellidae) on okra. Pest manage. in Hortic. Ecosyst. 18: 149-153.

Jayarao, B., S.B. Abulkhader, L.K. Naik and M.M. Vinaykumar. 2015. Assessment of Biology and morphometric characteristics of different stages of leafhopper, Amrasca biguttula biguttula (Ishida) on okra. Bisscan. 10: 671-674.

Kaur, S., K.K. Ginday and S. Singh. 2015. Economic threshold level (ETL) of okra shoot and fruit borer, Earias spp. on okra. Afr.J. Agric. Res. 10: 697-701. https://doi.org/10.5897/ AJAR2013.8273

Liu, R.H. 2003. Health benefits of fruit and vegetables are from additive and synergistic combinations of phytochemicals. Am. J. clin. Nutr. 78: 517S-520S. https://doi.org/10.1093/ ajcn/78.3.517S

Mandal, S., S. Sah and S. Gupta. 2006. Efficacy and economics of biopesticide and insecticide combinations against okra pests. Int. J. Agric. 
Sci. 2: 377-380.

Manero, J., C. Phillips, B. Ellison, S.Y. Lee, S.M. Nickols-Richardson and K.M. ChapmanNovakofski. 2017. Influence of seasoning on vegetable selection, liking and intent to purchase. Appetite. https://doi.org/10.1016/j. appet.2017.04.035

Misra, H. and B. Senapati. 2003. Evaluation of new insecticides against okra jassid (Amrasca biguttula biguttula). India. J. Agric. Sci. 73: 576-578.

Rawat, R.R. and H.R. Sadu. 1973. Estimation of losses in growth and yield of okra due to Empoasca devastans (Dist.) and Earias spp. India. J. Entomol. 35: 252-254.

Schreiner, I. 2000. Okra leafhopper (Amrasca biguttula) Ishida. Agric. Pest the Pacific (ADAP).pp. 90-2.

Sharma; G.N. and Sharm, P.D. 2001. Biology and development of cotton leafhopper (Amrasca biguttula biguttula Ishida) on different genotypes of okra (Ambelmoschus esculentus L. Moench). Crop Res. 14, 487-492.

Sharma, A. and R. Singh. 2002. Oviposition preference of cotton leafhopper in relation to leaf-vein morphology. J. Appl. Entomol. 126: 538-544. https://doi.org/10.1046/j.14390418.2002.00697.x

Srinivasa, R. and R. Rajendran. 2003. Joint action potential of neem with other plant extracts against the leafhopper Amrasca devastance (Distant) in okra. Pest manage. Econ. Zool. 10: 131-136.

Sharma, O., S. Bantewad, N. Patange, B. Bhede, A. Badgujar, P. Ghante, M. Kadam, S. Bhagat and A. Kumari. 2015. Implementation of Integrated Pest Management in Pigeonpea and Chickpea Pests in Major Pulse-Growing Areas of Maharashtra. J. Integr. Pest Manage. 6.

Subhani, A. 2001. Impact of some agronomic practices on paddy field soil health under varied ecological conditions: I. Influence soil moisture. 11: 39-48.

Zala, M.B. 2013. Evaluation of schedule and threshold based insecticidal application strategies on concentration and active ingredient against sucking pests in okra, Anand Agric. Univ. Anand. 